\title{
Our Shared Japan: Contemporary Spaces of Love and Exoticism in Irish Women's Poetry
}

\author{
Arancha Rodríguez-Fernández \\ Universidade de Santiago de Compostela, Spain
}

\begin{abstract}
Copyright (c) 2020 by Arancha Rodríguez-Fernández. This text may be archived and redistributed both in electronic form and in hard copy, provided that the author and journal are properly cited and no fee is charged for access.
\end{abstract}

\begin{abstract}
The aim of this paper is to analyse the new perspectives on the locus amoenus put forward by contemporary women poets in Ireland, in particular those by the female authors included in the anthology Our Shared Japan, edited by Irene De Angelis and Joseph Woods (2007). This paper argues that these writers provide alternatives to traditional pastoralism that trigger new reflections on women's identities and subjectivities. As Donna L. Potts asserts, some constitutive aspects of the pastoral tradition are "the relationship between nature and human nature, and between the present and the mythicised past, the motif of transformation, etc." (9). These aspects will be scrutinised in the context of travel to the new, exotic space of Japan. The alterity that the poetic voices meet with in their travel provides them with new perceptions of themselves and their affective life in relation to the environment. This renegotiation of identity is mostly made through the body, which becomes a tool for knowledge and communication. The heterotopia (Foucault) of the trip, therefore, provides the perfect space for the poetic subjects to interact, change and reflect about their identity, their sense of belonging or alienation and the impact of travel on their emotional life.
\end{abstract}

Key words. Irish Poetry, Contemporary Poetry, Women's Poetry, Space, Love.

Resumen. Esta investigación tiene como objetivo analizar las nuevas perspectivas sobre el locus amoenus presentadas por poetas contemporáneas en Irlanda, particularmente aquellas autoras incluidas en la antología Our Shared Japan, editada por Irene de Angelis y Joseph Woods (2007). Este artículo argumenta que estas escritoras proporcionan alternativas al pastoralismo tradicional que desencadenan nuevas reflexiones sobre las identidades y subjetividades de las mujeres. Como asegura Donna L. Potts, algunos aspectos constitutivos de la tradición pastoral son "the relationship between nature and human nature, and between the present and the mythicised past, the motif of transformation, etc." (9). Estos aspectos serán analizados en el contexto de los viajes al nuevo y exótico espacio de Japón. La alteridad que las voces poéticas encuentran en su viaje les proporciona nuevas percepciones de sí mismas y de su vida afectiva en relación con el entorno. Esta renegociación de la identidad se realiza 
principalmente a través del cuerpo, que se convierte en una herramienta de conocimiento y comunicación. La heterotopía (Foucault) del viaje, por lo tanto, proporciona el espacio perfecto para que los sujetos poéticos interactúen, cambien y reflexionen sobre su identidad, su sentido de pertenencia o alienación y sobre el impacto del viaje en su vida emocional.

Palabras clave. Poesía irlandesa, poesía contemporánea, poesía de mujeres, espacios, amor.

\section{Introduction}

During the second half of the twentieth century most of the European societies got to know what was called the welfare state. After the Second World War, and through Keynesian politics, communities that had never had the chance to inhabit a state of well-being were given that chance. One of the most interesting changes regarding the arts was the possibility to travel, and not only to places that were historically and geographically connected, but almost anywhere. The Irish society and its authors, therefore, were given the possibility to go beyond the anglophone world and culture and this possibility translated into an increasing number of books inspired by travel. New spaces, as exotic and different from their homeland as Japan, produced what Seamus Heaney, in his commentary on the inspiration offered by oriental countries, calls "the shock of the new" (211) in the epilogue to the collection we are about to analyse. Regarding the topic of Japanese literature in particular, Heaney also asserts elsewhere that "in the course of the century, as empires and ideologies contended for supremacy and atrocities were committed on a scale unprecedented in human history, writers became desperately aware of the dangers of rhetoric and abstraction. ... The chastity and reticence of Japanese poetry grew more and more attractive" (Ohno 6).

The anthology Our Shared Japan was published in 2007 by Dedalus Press and contains poems by eighty-five Irish poets, women and men. Irene de Angelis and Joseph Woods confirm that "both explicitly and implicitly, the poems in this anthology represent responses to the subject and influence of Japan" (15). Regarding the poems we are about to deal with, they are not so much inspired by form - haiku, tanka or other Japanese forms of poetry - but by content. This anthology contains works from very prominent voices, such as Sinéad Morrisey, Paula Meehan, Mary O'Donnell, Nuala Ní Dhomhnaill and Ruth Carr, among others, and explores a new sense of place and intimacy related to the idea of the foreign. The aim of this article is to analyse the particular affects and bonds that come together with the natural space of Japan and how this natural dislocation inspires the production of alternative variations of poetic subjects and subjectivities. ${ }^{1}$ Although male poets also participate in this collection, this paper focuses on the interrogation of the traditional locus amoenus by those women poets from the beginning of the twenty-first century who are included in Our Shared Japan. This focus aims to fill a gap in the research on women's poetry dealing with the multifarious relations between Ireland and Japan - on the contrary, we can find criticism on male poets dealing with this subject matter, as is the case with Seamus Heaney, Thomas Kinsella, etc. Other concomitant issues of interest for comparative literature are the dislocation of women subjects, the idea of liminality and the (re)creation of identities, all of these as affected by gender roles.

The poems selected for this article not only show the increased Irish interest in Japanese culture, but also the new paths of post-pastoral writing proposed by women and their relationship with a new conception of love and intimacy. ${ }^{2}$ Being the symbolic meaning of space one of the most recurrent topics in Irish poetry, the strategies used by women poets to redefine aspects of traditional value for their national literature, such as landscapes or domestic locations, open the way to writing about new and exotic spaces. The recreations of space women 
writers show in the poems will be analysed through the lens of topoanalysis. The term topoanalysis was coined by the French philosopher Gaston Bachelard and can be found in his essay The Poetics of Space described as follows: "the psychological study of the sites of our intimate life" (38). The use of topoanalysis may suggest a number of possibilities, such as the study of spaces related to singular attachments in communities linked by nationality, race or gender. But it can also be applied to the study of singular works of art and their particular relationship with spaces. To think about Japan from locations outside Japan itself could bring about various associations and connotations ranging from the traditional idea of Japan - the sensuality of the geishas and calamities such as Hiroshima in the Second World War - to the enormous technological cities of the twenty-first century.

The interest of Our Shared Japan and the poems chosen for analysis lies precisely in how the various Japanese identities affect the bonds and emotions of the poetic voices. Moreover, this space of the foreign could be defined as what Michel Foucault calls a heterotopia: a place "that does exist and that is formed in the very founding of society - which is something like a counter-site, a kind of effectively enacted utopia in which the real sites, all the other real sites that can be found within the culture, are simultaneously represented, contested, and inverted" (47). This concept of heterotopia is of relevance to our research both because it entails the possibilities of transformation facilitated by the foreign and the trip itself and also because this dislocation favours the contact of the poetic voices with new natural spaces which are not constrained by Irish social frameworks, as we will see throughout this article.

By inhabiting Japanese locations, the female subjects analysed in this paper are able to redefine their identities and sympathise with the atmosphere around them, mostly natural, breaking the stereotypes attached to land and women in Ireland, where the symbolic feminisation of the nation, and therefore the land, creates an idea of the female body as a passive territory to be invaded by others. This idea of "Mother Ireland" as a woman has been influenced and enhanced by the power of the Catholic church and the Celtic imaginary. As Manuela Palacios and Laura Lojo claim, the stereotype of Irish rural society and its intimate and sentimental relationship with nature "has made of landscape a very thorny topic for present-day writers. Some contemporary women poets even inscribe the breach with pastoralism along gender lines" (19). Precisely because of the change of locations, women subjects in Our Shared Japan tend to challenge the rural imaginary by performing new and freer subjectivities. This inversion of normality, as we will see throughout the article, introduces a number of variables related to affection, bodies and conceptions of the human and the non-human that are stimulated by the new space and the possibilities it brings. This new space could even be conceived, according to the Spanish philosopher Alicia Puleo, as an "ecogarden", a space out of the constraints of society (17).

\section{The Outsider's Gaze}

Some of the women-authored poems in Our Shared Japan provide us with the gaze of an outsider. Conscious of the experience of being abroad, the poetic voices look at their surroundings and the relations created there, sometimes recreating stereotypes about the country they are in. A good example of this is Sinéad Morrissey's poem "Nagasawa in Training":

Thirty years, say, since you left your father's temple for your father's mother temple in Kyoto. $\cdots$ 
Before the years came with their appointments, their daughters, a neighbourhood to pray for and a cancer constituency, sex was a stark to you

as the room of nothing you were building in your head. (120-30)

On the one hand, we find in this gaze the condition of the tourist, a critical distance between the "I", understood as a subject connected to her/his national, and even Eurocentric, identity, and the "other". Even though the main topic of the poem - sex as a desirable taboo and the way women are supposed to behave - may come as universal, Morrissey emphasises the distance between the speaker and the object by referring to a "you" and mentioning the temple as a sign of otherness. John Urry coined the concept of "tourist gaze" (3) to define this new condition that came with the globalised world and its continuous mobility. In this particular case, it is interesting to observe the presence of the temple, as a Japanese and thereby foreign element in the narrative, as well as the subtle connotation of control and even repression involved in the lifestyle described in the poem. But, on the other hand, the poetic persona analyses quite strongly the affections that surround her, instead of ignoring them. Even from a clearly Eurocentric point of view, full of preconceptions, the poetic voice becomes a voyeur of the love of others, a spectator with a will to interpret and elaborate a story of affections and sexuality. As Urry asserts, "tourism always involves corporeal movement and forms of pleasure and these must be central in any sociology of diverse tourisms. In that sense the tourist gaze always involves relations between bodies that are themselves in at least intermittent movement. Bodies moreover perform themselves in-between direct sensation of the 'other' and various sensescapes" (3). On the other hand, even from this outsider's point of view, the condition of foreignness brings the possibility to fantasise with the love of others by, as Irene de Angelis puts it, "the gentle art of disappearing" (3). Even though the anonymity in this context is shared, the concept of tourist gaze is not completely homogeneous. Coming back to John Urry, "in a simple sense we can talk of the globalising of the tourist gaze, as multiple gazes have become core to global culture sweeping up almost everywhere in their awesome wake" (7).

The preconceived ideas of Japan do not always relate to a closed and oppressive society. They sometimes recreate the traditional natural spaces of Japan in order to develop a narrative of romance, as is the case in the following poem by Julie O'Callaghan:

They lie together

all night whispering

and touching cheeks.

The shutters are open

that face the garden;

they dread the first

bird calls that start

the morning off. (150)

Observing an other, when it comes to love, allows poetic voices to describe and analyse it without the sentiment and pain sometimes carried when narrated by a first person. Moreover, the natural Japanese imaginary present in the poem - the garden, the bird - contributes to the creation of a new bucolic atmosphere which brings possibilities beyond the already well-known Irish landscape and which is devoid of its many connotations. While Irish landscapes have been traditionally associated to the "imaginary Irish peasant", in Edward Hirsch's words (1116), ${ }^{3}$ a figure of origins and the living embodiment of the Celtic imagination, the new natural sites of Japan do not connect the poetic subjects with any of these roles. As Donna L. Potts asserts in 
Contemporary Irish Poetry and the Pastoral Tradition, Irish postcolonial writers invite their readers to "look beneath the surface of the power structure" (140). In recent times there has been a reconsideration of the position of Irish poets in relation to landscape, the pastoral tradition and, therefore, the idea of locus amoenus - a pleasant space shown in literary works as the perfect place for lovers to meet. Those poets who lack direct experience of the land and the experience of working it tend to romanticise nature much more, even in an Irish context, as affirmed by Potts (ix). This romanticisation increases with the exoticism of the foreign, that shock of the new that Heaney referred to in the epilogue of this anthology. Following this romantic recreation, Mary O'Donnell mixes space and lovers and presents a kind of ode to love in her "Haikus on Love and Death":

The red lips of June,

Shirts of sun, ribbons of moon, How radiant is love! (154)

The poetic persona constructs here an idealised look at love and affection caused by the impression of the new space of Japan. Traditional pastoralism in Irish literature has been so closely related to certain roles for women, such as the relation between nature and women, between mother Earth and maternity, the present and the mythicised past, etc., that the existence of a new and foreign space seems to open up new possibilities. These possibilities for the female poetic personas include the capacity to redefine their own roles in the relationships they establish without being closely constrained by the traditional figures that would be present in this definition when in Ireland.

\section{Exotic Romance}

The new view on love experienced by some of the poetic voices does not only remain in their fantasy. Some of them become participants of this love, not only as spectators, thereby emphasising the alternatives brought about by the new space of Japan.

When speaking about love and women, we must remember that, as the emotional turn in scholarship has shown us in recent years, the conception of love is historically contingent. ${ }^{4}$ Somehow, the social understanding of womanhood in our patriarchal occidental societies, not only in the Irish society, has been constructed around the idea of shame. In the Irish society, in particular, this conception of womanhood or the feminine is emphasised by the power of the Catholic church and its beliefs. Being Catholicism the main religion in Ireland and thereby having a deep connection to its national identity, the ideology of the Church represents a powerful social force. When it comes to women or gender, as we have observed in recent years with issues such as abortion or LGTBIQ+ marriages, the Catholic Church in Ireland represents a very conservative view on society which perpetuates a female role model attached to the idea of the housewife, this is: women as delicate mothers and carers. Therefore, society has been strongly focused on the inhibition of female desire, among other things, and on its social punishment when expressed. Somehow the role of a good woman following these parameters is associated with passivity and concealment in relation with her own body. Only maternity is accepted, but even in that case, its bodily experience remains hidden and silenced. As Sarah Ahmed affirms in The Cultural Politics of Emotion: “The use of metaphors of 'softness' and 'hardness' shows us how emotions become attributes of collectives, which get constructed as 'being' through feeling. Such attributes are of course gendered: the soft national body is a feminised body which is penetrated or invaded by others" (2). This social construction shapes an idea of the female body as passive and, therefore, all its drives - the ones which come from the female herself - as shameful, even more so when addressed in public discourses, such as 
poetry. The poet Mary O'Donnell, for example, when asked about erotic poems, responds the following: "I have always avoided writing love or erotic poetry, because it's sloppy, selfindulgent rubbish sometimes. But those three or four just had to be written. ... It's difficult to talk about them, because they're about the zones between what is acceptable socially and what is not. It's not a favourite subject in this country" (Wilson 23). The shame associated with female eroticism relates to both the imperative social Catholicism and the prevalent idea of the Irish peasant as a pure and innocent figure. This idea at the same time relates itself with Irish nature and its Celtic roots, establishing a link between the role of women as mothers and carers of the nation and the Irish landscape.

Ireland, in particular, incorporates a third gendered characteristic alongside both the construction of womanhood in occidental societies and the role of women as established by the concept of the Irish peasant and Catholicism, and that is the idea of the nation as a feminised body or territory, that belongs to everybody but herself. It emphasises the idea of an identity shaped by others -these others being invariably men- an essentialist view of a fertile and sensitive feminine body which has the objective of giving birth to children of the mother country.

When relocation occurs, a new set of boundaries is established, and thereby a land with no connotations regarding female bodies, as well as a society that does not appear as dangerous for the female subjects. Love and desire are much freer in this space which does not follow the rules applied back home and, at the same time, does not imply new ones either. That is what Michel Foucault would call a heterotopia. The poetic subjects in Our Shared Japan are discovering a space outside of everything, a sort of experience that comes with the idea of tourism and travelling, something fatuous, something that appears appropriate to let that overly repressed desire out.

It is not a surprise that new, natural spaces may provide a sense of luxury and enjoyment, then. But the component of the exotic country, outside the homeland and, therefore, outside the judging looks of others, allows the poetic voices to experience romantic interactions, not necessarily long ones, but filled with passion, even more passion than they could feel when in Ireland. There is no expectation other than to feel pleasure, and the condition of being a tourist, of being there only for a short time, provides the perfect situation. A perfect example of this would be Yvone Cullen's "Kabuki”:

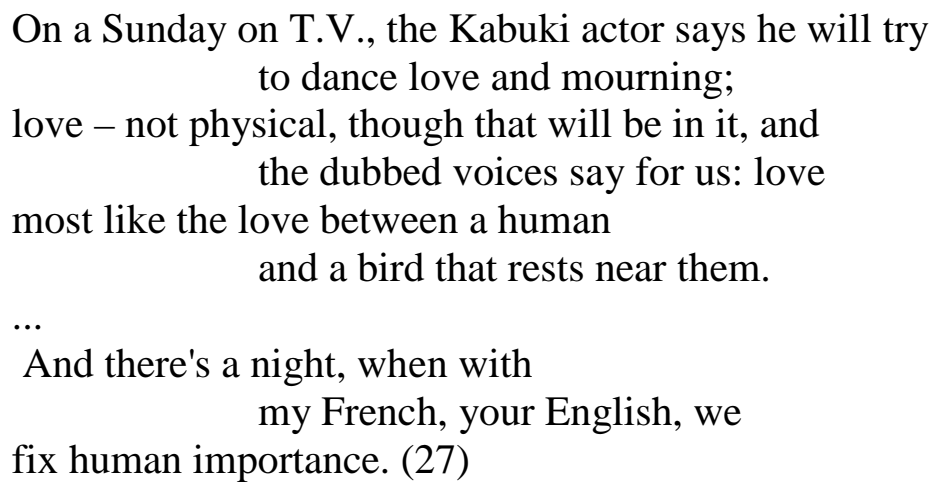

The foreign location and the condition of traveller produces an empowerment in the poetic voice. This new condition brings up, "a discourse in which women are empowered as desiring subjects as opposed to desired objects", in Irene Gilsenan Nordin's words (6). The reference to living the romance lightly as well as the impossibility to communicate in the same language, which does not seem to matter - "my French, your English" - remind us of an erotic, nomadic, and adolescent relationship, impossible in their place of origin, where romantic interactions are marked by limits, norms, marriage or, at the very least, the opinion of others. 
This delocalisation incorporates one more characteristic: the occidental view on difference. The "orientalist" perception of Japan, which tends to be sexualised and idealised, increases the eroticism and peacefulness of the context. As Rosen asserts:

Western images and metaphors for Japan are not all negative, of course - a romantic version of Orientalism paints a picture of Japan whose sophisticated culture with its indigenous traditions are in close harmony with nature (a myth popular in Japan, as well, it might be added); tiny bonsai trees, exotic geisha girls in kimono, manicured rock gardens, the unfathomable mysteries of Zen Buddhism, shiatsu and macrobiotic cooking, signify for us a people who are deeply intuitive and aesthetically attuned in a way that we are not.

The vision expressed in the above quotation leads the poetic voices to eroticise even quotidian moments or actions which would have a completely different meaning in their homeland, as we can observe in Ruth Carr's poem "Mushroom”:

I am rinsing milk white mushrooms under the tap. Your mouth opens birdlike to gulp all the world it can,

incautious and whole. (12)

The empowerment of the poetic voice does not stop there: in several of these poems, we can appreciate bodies that do not age, or at least their ageing is not important. Sexual intercourse is unconstrained by the rules that would normally establish its boundaries. The transitional space of travel invests the poetic voices with a liminality for themselves, a different reality where to enjoy love without frontiers. As Patricia Simons says when analysing long-lasting characteristics of love through the centuries, "separation from the everyday world is a key theme, as is emphasising unending, leisurely pleasure". The figure of the bird appears again not only as a symbol of freedom but accentuating the relationship between the human subjects and nature, as in the poems written by Julie O'Callaghan and Yvone Cullen. Nevertheless, in Ruth Carr's poem in particular the bird is being fed, which we could understand as a figure of both eroticism and rebellion against the behaviour people are not supposed to have in public. In this poem both the poetic subject itself and the lover are portrayed in a childish way, precisely as the opposite of the obedient adults who are expected to follow the social norm in Ireland.

Something of the kind occurs in the poem "The Flower Master", by Medbh McGuckian, in which the poetic subject is subtly taken by the lover into the new exotic context through nature and flowers, symbolising passion and eroticism:

We slip the thready stems of violets, delay

The loveliness of the hibiscus dawn with quiet ovals,

Spirals of feverfew like water splashing,

The papery legacies of bluebells. We do

Sea-fans with sea-lavender, moon-arrangements

Roughly for the festival of moon-viewing. (116)

The infantile, even the naïve in the case of Medbh McGuckian, that slow and innocent way of getting to know the foreign, of letting others lead them into love and eroticism, is somehow the reaction that allows the female poetic subjects to abandon their traditional role and perform 
their alter-egos. Another good example of that would be the poem "Karaoke in the Glasshouse" by Deirdre Catmill:

I'm under surveillance from too many lost souls, remembering when they were flesh and touched my flesh. I sang an unholy duet with the banshee when you flirt with death's girl, there's no room for regrets. The glass eyes fatten my reflection. I hang in limbo in a hall of mirrors, two-faced, half way to a peaceful universe. (21-2)

As we can see in this poem written by Deirdre Catmill, as well as in many others, the process of the trip carries with it an experience of discovering the other in the self as the poetic subject acknowledges that other-reality. This leads to a process of reconciliation with the double face of the feminine poetic subjects: they are not one thing, nor the other - they are not in Ireland anymore, nor do they live in Japan. In this mixture of motifs, as observed in "Karaoke in the Glasshouse”, women appear to find peace in their heterogeneous identity. The liminality women subjects are placed in, because of their geographical circumstances, but also because of the freedom of their role, seems to open a variety of possibilities that far from bothering them, help them to explore their own selves.

\section{Liminality and Transformation}

In the liminal space of the trip, of the foreign, female bodies experience a different reality, as we could observe in the previous poem. Besides empowering them, this liminality entails some kind of transformation. It becomes a self-discovering journey that gives knowledge through interaction, knowledge about love, and also about the poetic voices themselves. This knowledge, depicted in the different and exotic surroundings of Japan, recreates itself not only as an internal journey but a conjunction with the context. The atmosphere surrounding the poetic voices becomes not a place but something else: a space which is gradually practiced by them at the same time as they explore their social and personal cartographies. We can see this in the following poem by Rachael Hegarty, "There is No Love in Hykyu”:

\section{In a Japanese \\ Town called Matsue \\ Leaves fall. \\ Forgive me, my love, I am forgetting our once \\ Shared language. (77)}

In this poem, the poetic subject, strolling through the Japanese town of Matsue, willingly undergoes a metamorphosis. While walking through this Japanese place, she is not the host, she has no obligations and therefore she enjoys the trip. This enjoyment, somehow, produces a transformation: progressively she starts forgetting her old self to become someone else, free of her old emotional baggage. In my view, we can find in this flâneuse/tourist a kind of doppelgänger motif: affected by the new liminal space, the poetic voice incorporates an alter ego. In Katarzyna Poloczec's words, with this shift women poets "challenge the homogeneous and unified vision of identity in favour of pursuing the network of intensities and becomings that undergo continuous shapeshifting” (131). 
This shapeshift experienced by the poetic voice while in Japan becomes physically challenging in some women poets' work. Japan, in its complexity, between the traditional and the postmodern, appears as a place between nature and civilisation. In fact, being a hypertechnological country, Japan continues to profess beliefs such as the Shinto or shintoism, a native religion in which the spirits of nature are venerated. The perfect heterotopia Japan produces in its many "contradictions" not only allows the poets to introduce changes in their poetic voices but encourages them to break the classical dichotomies between human and nature, as well as between reason and emotion. That is the case of the poem "Blossom Time" by Katie Donovan in which she describes the experience of a poetic persona when encountering a procession of Japanese brides who seem to her as newborn birds:

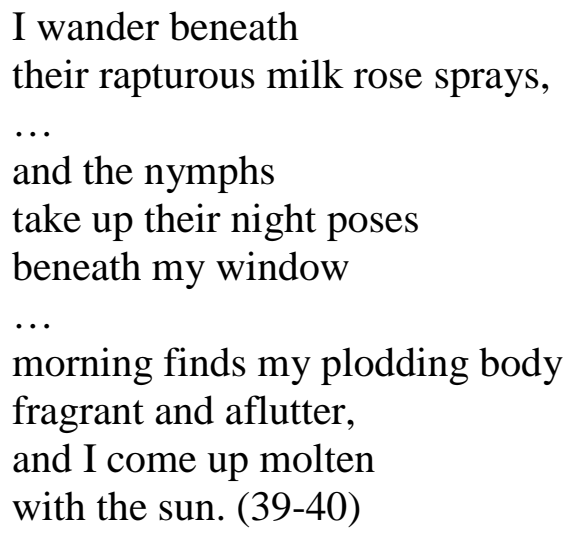

As we can understand while reading this poem, mentioning birds, nymphs, air and the atmosphere itself is not casual. Katie Donovan expresses in this text the urge of becoming something else while identifying with different beings in her surroundings, a very postmodern topic indeed and one related to both her national tradition and the new space of Japan. As Judith Butler maintains, "the boundary of the body as well as the distinction between internal and external is established through the ejection and transvaluation of something originally part of identity into a defiling otherness" (499). The motif of the transformation of the woman into a kind of natural being has had a big impact on Irish poetry, coming from the Celtic tradition of the relationship between human beings and the land. As affirmed by Manuela Palacios and Laura Lojo, "poetry inspired in Celtic mythology should be of particular interest for ecocriticism because of the allegedly mystical fusion of the Celts with the natural world both in their religious rites and in their day-to-day life" (90).

Again, the empowerment is present, and the body becomes something else, melting with the space that surrounds it and embracing the relationship between the human and the nonhuman. Thus, the body in transformation acts as a connection between self and world. Quoting Irene Gilsenan Nordin when speaking about metamorphosis of women's bodies in Irish poetry, the space created around them becomes "the place where consciousness is no longer master" (6). In this case, there is no need for a relationship with other human beings to feel a new kind of love and passion: the poetic voice itself, in the path of becoming, represents this love and becomes one with the atmosphere. In other words, no longer being a voyeur, but being one with "the other". That kind of relationship between the human and the non-human could be interpreted as an expanded relational self, a concept proposed by feminist ecocriticism, which does recognise the different selves as something else than human or non-human, but beings that live in interconnectedness with all others (Estévez-Saá and Lorenzo-Modia 129). Something similar was proposed by the posthumanist philosopher Rosi Braidotti with the idea of zoé: “an impersonal force that moves through us and connects us to the other creatures we share the world and our own bodies with”. 
Continuing with this ecocritical point of view, the Spanish philosopher and ecocritic Alicia Puleo proposes, following some ideas extracted from Epicureanism, the notion of a garden free of androcentrism which invites to calmness and reflection over oneself. In particular, Puleo maintains that "el jardín-huerto ecofeminista es un locus amoenus, ese lugar 'encantador', bosque o prado de la literatura clásica en el que tenían lugar los felices encuentros al margen de las convenciones sociales. Es un espacio alternativo, despojado de convenciones antropocéntricas, en el que encontrarse” (19).

In the poems we have seen, Japan and its landscape represent indeed a space in which female subjects can reflect upon their own selves and the others, even expand their feelings freely and without judgement, and in which they tend to identify themselves with other human and non-human subjects through observation. Still, in most of the poems we have analysed, poetic voices continue to look at the Japanese space, as well as Japanese women, as something they would like to turn into, something they desire and sympathise with, but an other, nonetheless. Alterity continues being an issue in most of them, but the Eurocentric, even patronising, point of view of the tourist is no longer present.

We can find something different in Pamela Greene's poem "Waiting for You”. In this poem, the female poetic subject, in the act of waiting for her lover, is trying to dress and act as a geisha. Nevertheless, he does not appear, and somehow nature responds to that absence empathising with her:

The wind rises.

You will not come now

and tomorrow the cherry blossom

will shed its petals, one by one. (66)

This connection between the cherry blossom and the abandoned female subject could be interpreted as a sort of communication between them, a metaphor of the expanded relational self we were talking about, but also as a kind of empowerment: not only do both the woman and the cherry blossom feel the absence and wither but they change as a consequence of that. That change could lead to a stronger consideration of the self in the non-androcentric garden Alicia Puleo referred to. This conception can explicitly be seen in Mary O'Donnell's Haikus on Love and Death:

The man is winter.

The girls swim like fish.

Hither in the deft ocean.

Minnows seeking warmth.

Woman in August.

Her body is a forest.

Here there is welcome. (153-154)

In these haikus, the female subjects are continuously introduced as beings looking for shelter and heat, in contraposition to men, who are described as cold - winter. Precisely in this identification we can understand the idea of Japan as a place that enhances the transformation of female subjects in all the different aspects of their lives: they become empowered, they connect with themselves but they also get along with different bodily transformations that identify them with animals. Thus, this transited territory becomes a place of opportunity in which both women and nature not only appear as something descriptive but, finally, alive, and 
completely in connection with all that is living in their surroundings. They, indeed, manage to acquire an identity of their own.

\section{Conclusions}

In conclusion, the appearance of a new space brings with it a number of possibilities for female poetic voices outside of the norms and boundaries that normally affect their relationships and bonds, especially those bonds with romantic attributes. The space of an exotic country, emphasised by the poetic voices' condition of the tourist, constitutes what Michel Foucault would call a heterotopia, this is, a liminal place outside of the norms that rule society.

In opposition to the known spaces of Ireland, related to particular experiences of being a woman in this country, the heterotopia of the exotic trip offers the poetic voices the possibility to reinvent themselves, becoming spectators, anonymous, alter egos or even an "other". Women, often associated to landscape, have traditionally represented the Irish nation in poetry, a canon that barely allows subversion and is often criticised by women authors. Nevertheless, the landscape of Japan, its complex and unknown spaces, provide women writers with the perfect setting to experiment new poetic voices and new paths, related to self-love, romantic interactions and freedom. Even if all of these experiences are pictured from the standpoint of a bourgeois, European woman, who can afford to travel and get lost in a foreign country, they definitely represent a paradigm of liberty and confidence for women when addressing sex, romance and even their own conception of the self.

Moreover, all these poetic texts reflect the spirit of the post-pastoral, defined by Donna L. Potts as "works that move from the anthropocentric viewpoint of pastoral, conveying a deep sense of the immanence in all natural things and recognising that our inner human natures can be understood in relation to external nature" (10). This shared spirit translates, in some of the cases, into a will for transformation that experiments and even breaks the boundaries of the body, the human and the non-human. The female poetic subjects end up appropriating the new space of Japan, which does not constitute an exotic or foreign space anymore, but a nonandrocentric place: an ecogarden, in Alicia Puleo's terms. In this ecogarden, the poetic voices experience love, bonds and also self-love and empowerment in a shared imaginary of freedom without labels.

\section{Notes}

${ }^{1}$ The author wishes to acknowledge the grant PGC2018-093545-B-I00 MCIU / AEI / FEDER, UE for the research project "The Animal Trope".

${ }^{2}$ A writing style that continues to include the land as an essential part of the writing, as the pastoral tradition did, but uses the presence of the land to share a postcolonial critique, a response to industrialization, to modernity and to the modifications of landscape, amongst others (Potts).

3 The idea of the "Irish peasant" was firstly introduced in popular culture by the English, as a colonial representation to mark a relationship of power with Ireland. Nevertheless, it was reappropriated by the Irish folk in order to construct a national symbol, idealizing Irish roots and associating the "Irish peasant" to virtues (also strongly related to Catholicism) such as purity, antimaterialism and organicism.

${ }^{4}$ The increasing interest in human emotions both in academic research and the public debate during the last decade is known as emotional or affective turn(s). It includes a variety of disciplinary perspectives on human emotions that endorse both public connections and private lives, as asserted by David Lemmings and Ann Brooks (8).

\section{Works Cited}

Ahmed, Sarah. The Cultural Politics of Emotion. Edinburgh: Edinburgh University Press and Routledge, 2004.

Bachelard, Gaston. The Poetics of Space. Boston: Beacon Press, 1994 (1958). 
Braidotti, Rosi. “The Amoderns. Thinking with Zoe”. Amodern, July 2016. 18 Jun 2020. https://amodern.net/article/amoderns-thinking-zoe/

Butler, Judith. Undoing Gender. Abingdon: Routledge, 2004.

De Angelis, Irene and Joseph Woods, ed. Our Shared Japan. Dublin: Dedalus Press, 2007.

Estévez-Saá, Margarita and María Jesús Lorenzo-Modia. "The Ethics and Aesthetics of Ecocaring: Contemporary Debates on Ecofeminism(s)”. Women's Studies 47. 2 (2018): 123146.

Foucault, Michel. “Of Other Spaces, Heterotopias”. Translated from Architecture, Mouvement, $\begin{array}{lllll}\text { Continuité, } & 1984 & \text { (1967). } & 18 & \text { Jun }\end{array}$ https://foucault.info/documents/heterotopia/foucault.heteroTopia.en/

Gilsenan Nordin, Irene, ed. The Body and Desire in Contemporary Irish Poetry. Dublin: Irish Academic Press, 2006.

Hirsch, Edward. “The Imaginary Irish Peasant”. PMLA 106. 5 (1991):1116-1133. JSTOR, 19 Jun 2020. https://www.jstor.org/stable/462684

Lemmings, David and Ann Brooks, ed. Emotions and Social Change: Historical and Sociological Perspectives. Abingdon: Routledge, 2014.

Ohno, Mitsuko. “Heaney, Japan and Mutual Affection”. Journal of Irish Studies 29 (2014): 36. JSTOR. 20 Aug 2020. https://www.jstor.org/stable/24367801

Palacios, Manuela and Laura Lojo, eds. Writing Bonds. Bern: Peter Lang, 2009.

Poloczek, Katarzyna. Towards Female Empowerment. The New Generation of Irish Women Poets: Vona Groarke, Sinéad Morrisey, Caitríona O'Reilly and Mary O'Donoghue. Lódz: Lódz University Press, 2015.

Potts, Donna L. Contemporary Irish Poetry and the Pastoral Tradition. Missouri: University of Missouri Press, 2011.

Puleo, Alicia H. Claves Ecofeministas para rebeldes que aman a la Tierra y a los animales. Madrid: Plaza y Valdés, 2019.

Rosen, Steven L. "Japan as Other: Orientalism and Cultural Conflict”. Intercultural $\begin{array}{lllll}\text { Communication, } & \text { November } & 2000 . & 18 & \text { Jun }\end{array}$ https://www.immi.se/intercultural/nr4/rosen.htm

Simons, Patricia. "Friday Essay: Finding Spaces for Love". The Conversation, 30 March 2017.18 Jun 2020. https://theconversation.com/friday-essay-finding-spaces-for-love74156

Urry, John. The Tourist Gaze. London: Sage Publications, 2002 (1990).

Wilson, Rebecca, ed. Sleeping with Monsters: Conversations with Scottish and Irish Women Poets. New York: Columbia University Press, 1990.

Received: 19 June 2020 Revised version accepted: 13 September 2020

Arancha Rodríguez-Fernández holds a degree in Journalism from Universidad Complutense de Madrid. She is currently working on her PhD in Universidade de Santiago de Compostela under the supervision of Dr. Manuela Palacios-González and has undertaken a research stay in University College Cork. Moreover, Rodríguez has presented her work in various national and international conferences. Her main research interests include Love Studies, Gender and Queer Studies, Comparative Literature and Literature of Female Authorship.

arancha.rodriguez.fernandez@usc.es 